\title{
ADAPTABILITY AND CROP CAPACITY OF POTATO VARIETIES IN CLIMATE TERMS IN UKRAINE
}

\author{
Sonets Tatiana ${ }^{1}$ \\ Kyienko Zinaida ${ }^{2}$
}

DOI: https://doi.org/10.30525/978-9934-571-89-3_110

Question concerning stability crop capacity of potato varieties in climate terms in Ukraine still the main problem now. One of the factors to get a high level of productivity of potatoes is to take into account the potential genetic adaptation of potato varieties to various soil-climatic zones of cultivation. The breeding genetic potential of the new varieties is used only for $37-50 \%$. So an important feature of varieties is them adaptivity to critical phases in ontogenesis and environmental particular factors influence [1, p. 203-204].

The latest period breeders are working on breeding of high potential varieties of potato different groups of ripeness depends on their reactions on meteorogical and agrotechnical forces.

The last several decades fluctuations in gidrotermical indexes are found in the same soil-climatic area which make important influence on particular features, qualities and crop capacity of plant as a result.

All those factors require to be more attentive to determine adaptivity potential of potato varieties in specific soil-climatic terms growing [2, p. 10-16].

In Ukraine are a lot of potato varieties different groups of ripeness and economic purpose which can satisfy needs of potato producers. For example, in 2018 year to Register of plant varieties in UA was registered 189 varieties as a UA (42\%) and foreign (58\%) breeding [3].

To take into account status and problems of potato producing in general different researching was made in order to determine adaptivity criteria which allowed to find

\footnotetext{
${ }^{1}$ Ukrainian Institute for Plant Variety Examination, Ukraine

${ }^{2}$ Ukrainian Institute for Plant Variety Examination, Ukraine
} 
among exist assortment varieties with high productivity which can be recommended to particular climate area growing.

The research was carried out on areas with soils most widespread for the Polissya and Forest-Steppe zone. General growing technology was applied to seedlings in researching area. The records and observations were carried out in accordance with the Guidelines for research on potatoes, methods of examination of varieties of potato plants and groups of vegetable, melon, spiced and flavored on the suitability for cultivation and use in Ukraine (VCU) etc [4, p. 50-100, 5, p. 5-18].

The main indicator for determining the general species adaptive response of the variety was yield. For this aim was calculated a coefficient of variety adaptivity per yield in year of growing to average yield of the year.

The criterion of adaptability of a variety, which is characterized by high adaptability in the test area, is the coefficient of adaptability (CA) with an index of 1.0 and above.

The annual coefficient of adaptability (CA) for variety demonstrates a ratio of the yield of a particular variety in the year of testing to the average variety yield of the year [6, p. 10-11].

The absolute average coefficient of adaptability (CA) is calculated as the ratio of the variety yield in research years to a long-term average variety yield.

During the years of the test, under the same conditions of cultivation, the varieties responded in different ways to conditions of the soil climatic zones in Polissya and the Forest-steppe of Ukraine in relation to the year of the test.

Analyzing the results, it was established that the coefficient of adaptability 1.0 and above indicates high adaptability of the variety in the soil-climatic conditions of the cultivation zone, despite the changes in weather condition during the growing season.

According to the absolute indices of the coefficient of adaptability (CAA) 1,0 and above, the tested potato varieties are in this order: in Polissya: 'ESMEE' - 1.12, 'CATANIA' - 1.06, 'Constance' - 1.03; in Forest-steppe: 'ESMEE' - 1.16, 'CATANIA' -1.12 , 'Constance' -1.00 . The best yield performed varieties according to the testing results from different years: in Polissya 'CATANIA' - 21,9 t/ha, CA 1,24; 'Yavir' - 21,2 t/ha, CA - 1,20; 'ESMEE' - 20,3 t/ha, CA - 1,26; in Foreststeppe 'CATANIA' - 24,2 t/ha, CA - 1,13; 'ESMEE' - 22,2 t/ha, CA - 1,34 'Constance' - 21,7 t/ha, CA - 1,01 (table 1).

Such varieties as 'CATANIA' and 'Yavir' in the Polissya, 'CATANIA' and 'Constance' in the Forest-steppe had the most positive reaction to the favorable growing conditions regarding the implementation of its genetic potential, namely the high yield. Such varieties are characterized by specific adaptability. In 2014, under favorable weather conditions, the increase in the yield of these varieties to the annual average variety index in Polissya $(17,6 \mathrm{t} / \mathrm{ha})$ was $4,3 \mathrm{t} / \mathrm{ha}$ and 3,6 t/ha, in the Foreststeppe $(21,4 \mathrm{t} / \mathrm{ha})$ was $2,8 \mathrm{t} / \mathrm{ha}$ and $0,3 \mathrm{t} / \mathrm{ha}$ respectively. Due to this the specific adaptive ability of the variety manifests itself at a high average variety yield of the year (table 2). 
Table 1

Yield of potato varieties and its coefficient of adaptability during the period of testing in the Polissya and Forest-steppe of Ukraine (2014-2016)

\begin{tabular}{|c|c|c|c|c|c|c|c|c|}
\hline \multirow{3}{*}{ Variety } & \multicolumn{4}{|c|}{ Yield, t/ha } & \multicolumn{4}{|c|}{ Coefficient of adaptability } \\
\hline & \multicolumn{3}{|c|}{ years } & \multirow{2}{*}{$\begin{array}{l}\text { Average in } \\
\text { period from } \\
2014 \text { to } 2016\end{array}$} & \multicolumn{3}{|c|}{ years (CA) } & \multirow{2}{*}{$\begin{array}{c}\text { Absolute } \\
\text { (CAA) } \\
2014-2016\end{array}$} \\
\hline & 2014 & 2015 & 2016 & & 2014 & 2015 & 2016 & \\
\hline 1 & 2 & 3 & 4 & 5 & 6 & 7 & 8 & 9 \\
\hline \multicolumn{9}{|c|}{ Polissya } \\
\hline CATANIA & 21,9 & 12,0 & 17,8 & 17,2 & 1,24 & 0,81 & 1,11 & 1,06 \\
\hline ESMEE & 17,1 & 16,8 & 20,3 & 18,1 & 0,96 & 1,13 & 1,26 & 1,12 \\
\hline Constance & 15,8 & 16,5 & 17,5 & 16,6 & 0,89 & 1,11 & 1,09 & 1,03 \\
\hline Ludmilla & 11,9 & 17,1 & 11,7 & 13,6 & 0,67 & 1,15 & 0,73 & 0,84 \\
\hline Yavir & 21,2 & 12,3 & 13,4 & 15,6 & 1,20 & 0,82 & 0,83 & 0,95 \\
\hline $\begin{array}{l}\text { Average variety } \\
\text { yield of the year }\end{array}$ & 17,6 & 14,9 & 16,1 & - & - & - & - & - \\
\hline $\begin{array}{l}\text { Variety yield of } \\
\text { many years }\end{array}$ & - & - & - & 16,2 & - & - & - & - \\
\hline \multicolumn{9}{|c|}{ Forest-steppe } \\
\hline CATANIA & 24,2 & 20,6 & 17,8 & 20,8 & 1,13 & 1,16 & 1,07 & 1,12 \\
\hline ESMEE & 21,1 & 20,8 & 22,2 & 21,4 & 0,98 & 1,17 & 1,34 & 1,16 \\
\hline Constance & 21,7 & 17,8 & 14,8 & 18,1 & 1,01 & 1,00 & 0,89 & 1,00 \\
\hline Ludmilla & 18,9 & 17,5 & 14,6 & 17,0 & 0,88 & 0,98 & 0,89 & 0,92 \\
\hline Yavir & 21,0 & 12,4 & 13,5 & 15,6 & 0,98 & 0,70 & 0,81 & 0,83 \\
\hline $\begin{array}{l}\text { Average variety } \\
\text { yield of the year }\end{array}$ & 21,4 & 17,8 & 16,6 & - & - & - & - & - \\
\hline $\begin{array}{l}\text { Variety yield of } \\
\text { many years }\end{array}$ & - & - & - & 18,6 & - & - & - & - \\
\hline
\end{tabular}

Table 2

Yield of potato varieties and its deviation from the average variety yield in the Polissya and Forest-steppe of Ukraine (2014-2016)

\begin{tabular}{|c|c|c|c|c|c|c|}
\hline \multirow{3}{*}{ Variety } & \multicolumn{3}{|c|}{ Yield, t/ha } & \multicolumn{3}{|c|}{$\begin{array}{l}\text { Deviation from the average } \\
\text { variety yield, } t / \text { ha }\end{array}$} \\
\hline & \multicolumn{3}{|c|}{ years } & \multicolumn{3}{|c|}{ years } \\
\hline & 2014 & 2015 & 2016 & 2014 & 2015 & 2016 \\
\hline 1 & 2 & 3 & 4 & 6 & 7 & 8 \\
\hline \multicolumn{7}{|c|}{ Polissya } \\
\hline CATANIA & 21,9 & 12,0 & 17,8 & 4,3 & $-2,9$ & 1,7 \\
\hline ESMEE & 17,1 & 16,8 & 20,3 & $-0,5$ & 1,9 & 4,2 \\
\hline Constance & 15,8 & 16,5 & 17,5 & $-1,8$ & 1,6 & 1,4 \\
\hline Ludmilla & 11,9 & 17,1 & 11,7 & $-5,7$ & 2,2 & $-4,4$ \\
\hline Yavir & 21,2 & 12,3 & 13,4 & 3,6 & $-2,6$ & $-2,7$ \\
\hline $\begin{array}{l}\text { Average variety } \\
\text { yield of the year }\end{array}$ & 17,6 & 14,9 & 16,1 & - & - & - \\
\hline
\end{tabular}


Ending of Table 2

\begin{tabular}{|c|c|c|c|c|c|c|}
\hline 1 & 2 & 3 & 4 & 6 & 7 & 8 \\
\hline \multicolumn{7}{|c|}{ Forest-steppe } \\
\hline CATANIA & 24,2 & 20,6 & 17,8 & 2,8 & 2,8 & 1,2 \\
\hline ESMEE & 21,1 & 20,8 & 22,2 & $-0,3$ & 3,0 & 5,6 \\
\hline Constance & 21,7 & 17,8 & 14,8 & 0,3 & 0,0 & 1,8 \\
\hline Ludmilla & 18,9 & 17,5 & 14,6 & $-2,5$ & $-0,3$ & $-2,0$ \\
\hline Yavir & 21,0 & 12,4 & 13,5 & $-0,4$ & $-5,4$ & $-3,1$ \\
\hline $\begin{array}{l}\text { Average variety } \\
\text { yield of the year }\end{array}$ & 21,4 & 17,8 & 16,6 & - & - & - \\
\hline
\end{tabular}

Using the coefficient of adaptability 1.0 and above both to the annual and average yield of many years, allows to characterize the productive capacity of the variety to the soil and climatic conditions of the growing area.

The cultivation of potato varieties with high adaptability and permanent yield in respect of a certain soil and climatic zone is a significant factor in increasing the production of potato varieties, especially high-category seed material for varieties rotation and replacement. Such varieties of potatoes in the Polissya are: 'ESMEE', 'CATANIA', 'Constance'; in Forest-steppe: 'ESMEE', 'CATANIA', 'Constance'.

\section{References:}

1. Osypchuk A. A. (2002). Genetychnyj potencial kartopli [Genetic potential of potatoes]. Kartoplya, vol. 1, pp. 203-204.

2. Podgayeczkyj A. A. (2014). Adaptaciya i yiyi znachennya dlya selekciyi ta vyrobnycztva silskogospodarskyx kultur, tomuchysli kartopli [Adaptation and its importance for the selection and production of crops, including potatoes]. Potato Growing in Ukraine, vol. 1-2, pp. 10-16.

3. Ministry of Agrarian Policy and Food of Ukraine (2018). Derzhavnyj rejestr sortiv roslyn, prydatnykh dlja poshyrennja $v$ Ukrajini [State register of plant varieties, suitable for distribution in Ukraine]. Kyiv: Ministry of Agrarian Policy and Food of Ukraine.

4. Metodychni rekomendatsii shchodo provedennia doslidzhen $\mathrm{z}$ kartopleiu [Guidelines for conducting investigation of potatoes]. (2002). Nemishaieve: N.p. [in Ukrainian], pp. 50-100.

5. Tkachyk S. O. (ed.) (2014) Metodyka provedennya ekspertyzy sortiv roslyn kartopli ta grup ovochevyx, bashtannyx, pryano-smakovyx na prydatnist do poshyrennya v Ukrayini (PSP) [Methodology for carrying out the examination of varieties of potato plants and groups of vegetable, melon, spiced and flavored on the suitability for distribution in Ukraine (PSP)], Kyiv: TOV "Nilan-LTD", pp. 5-18.

6. Maljavko A. A., Maruhlenko A. V., Borisova N. P. (2012). Kojefficient adaptivnosti sorta kartofelja opredeljaet ego produktivnost\&apos [The coefficient of adaptability of a potato variety determines its productivity]. Potatoes and vegetables, no. 3, pp. 10-11. 